\title{
Splenic myelolipoma in a dog
}

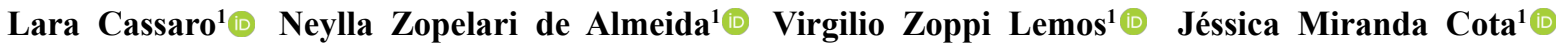

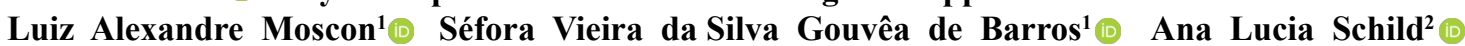 Clairton Marcolongo-Pereira ${ }^{1^{*}}$ (D)}

${ }^{1}$ Faculdade de Medicina Veterinária, Centro Universitário do Espírito Santo(UNESC), 29703-858, Colatina, ES, Brasil. E-mail: clairton.marcolongo@terra.com.br ${ }^{*}$ Corresponding author

${ }^{2}$ Laboratório Regional de Diagnóstico (LRD), Universidade Federal de Pelotas (UFPel), Pelotas, RS, Brasil.

ABSTRACT: Myelolipoma is a benign neoplasm composed of mature adipocytes and hematopoietic elements. This tumor is rare in dogs and cats and can develop in several organs and tissues. This report describes a case of splenic myelolipoma in a dog characterizing its clinical-pathological and ultrasonography aspects. A 9-year-old, female, mixed-breed, castrated dog was referred to the veterinary hospital with increased abdominal circumference. Ultrasonography revealed splenomegaly with masses of not measurable dimensions along the entire length of the parenchyma. The spleen was removed, and a fragment was sent for histopathological analysis. Macroscopically, the spleen was enlarged, with irregularly nodular growths that project above the surface of the organ. Nodules were red with small yellow areas. Microscopically, the spleen was effaced by a well-demarcated and not encapsulated mass composed of histologically well-differentiated neoplastic adipose tissue with islands and nests of varying proportions of hematopoietic elements. Histological examination confirmed the diagnosis of myelolipoma. Myelolipomas are observed on ultrasound images as hyperechoic masses or nodules with homogeneous echo texture. Here, ultrasound appearance involved mixed echogenicity and heterogeneous echotexture, due to the mixture of fat and non-fatty material components of the tumor.

Key words: canine, spleen, ultrasonography, myelolipoma.

Mielolipoma esplênico em um cão

RESUMO: Mielolipoma é uma neoplasia composta por adipócitos maduros e elementos hematopoiéticos. Este tumor é raro em cães e gatos e pode se desenvolver em diversos órgãos e tecidos. Descreve-se um caso de mielolipoma esplênico em um cão caracterizando seu aspecto clínico-patológico e ultrassonográfico. Um canino, fêmea, castrada, SRD, de 9 anos de idade foi encaminhada para o Hospital Veterinário com um aumento na circunferência abdominal. A ultrassonografia abdominal revelou esplenomegalia com massas de dimensões imensuráveis em toda a extensão do parênquima. Foi realizada esplenectomia total e um fragmento do baço foi encaminhado para análise histopatológica. Macroscopicamente o baço estava aumentado de tamanho, com crescimentos nodulares irregulares que se projetam acima da superficie do órgão. Os nódulos eram vermelhos com pequenas áreas amarelas. Microscopicamente foi observada uma massa bem demarcada e encapsulada composta por tecido adiposo neoplásico bem diferenciado, com ilhas e ninhos de elementos hematopoiéticos de proporção variada. O diagnóstico foi confirmado pelo exame histopatológico. Mielolipomas são observados nas imagens ultrassonográficas como massas hiperecóicas ou nódulos com ecotextura homogênea. Neste caso, o achado ultrassonográfico mostrou ecogenicidade mista e ecotextura heterogênea, provavelmente devido à mistura dos componentes do tumor com material gorduroso e não gorduroso.

Palavras-chave: cão, baço, ultrassonografia, mielolipoma.

Myelolipoma is a benign neoplasm composed of mature adipocytes and hematopoietic elements (CARDY \& BOSTROM, 1978). This tumor is rare in dogs and cats (MORANDI et al., 2007) and can develop in several organs and tissues (ALRUKIBAT \& BANI, 2006). Most myelolipomas are endocrinologically inactive, but when they occur in the adrenal glands, they can generate endocrinopathies, such as Cushing's syndrome and hyperaldosteronism (NAI et al., 2007). In the spleen, myelolipomas have been described in elderly dogs, usually older than nine years of age (BANDINELLI et al., 2011). These tumors are mostly asymptomatic, but can cause nausea, vomiting, discomfort, and increased abdominal volume (ALVES et al., 2006).

A definitive diagnosis of a myelolipoma is made on the basis of histopathological examination of the lesion, but ultrasonography can be informative 
for this tumor (CARRILLO et al., 2012). Treatment involves total splenectomy (AL-RUKIBAT \& BANI, 2006). Thus, we report in detail a case of splenic myelolipoma in a dog, emphasizing the corresponding clinical and ultrasound characteristics and histopathological findings of this disease.

A 9-year-old, female, mixed-breed, castrated dog was referred to the veterinary hospital with increased abdominal circumference, but without clear discomfort or other clinical signs, with onset approximately two months prior. The animal had a history of a mammary tumor and was being treated for canine ehrlichiosis.

Hematological examinations were performed, such as those of the full blood count (FBC), along with biochemical and imaging examinations (ultrasonography). The FBC showed discreet leukopenia due to lymphopenia, monocytopenia, and thrombocytopenia. The serum biochemical profile was within the normal range. On ultrasonography, splenomegaly was detected with masses of unmeasurable dimensions along the entire length of the parenchyma. The echotexture of the spleen was heterogeneous, with an irregular capsule and mixed echogenicity (Figure 1A). There were no changes in other organs of the abdominal cavity.

Abdominal exploratory laparotomy was performed, and an enlarged spleen was observed, which was multinodular with red and yellow areas on the capsular surface of the nodules (Figure 1B). Total splenectomy was performed, and an organ fragment was histopathologically analyzed. Macroscopically the spleen was enlarged, with irregularly nodular growths that project above the surface of the organ. The nodules were red with small yellow areas.

The excised mass was fixed in $10 \%$ neutral buffered formalin, processed routinely for histological examination, and embedded in paraffin blocks. Sections were stained with hematoxylin and eosin and examined histologically. Sections of the spleen were effaced by a well-demarcated and unencapsulated mass composed of histologically well-differentiated neoplastic adipose tissue with islands and nests of varying proportions of hematopoietic elements (Figure 2A, B). Cellular atypia and mitoses were not observed.

The animal showed clinical improvement, and no changes were observed at 3- and 9-month follow-ups.

The diagnosis of splenic myelolipoma was based on the ultrasound findings and histological characteristics of the tumor. Myelolipomas are rare tumors that contain mature fat and hematopoietic elements, and they are more frequently reported in the spleen of dogs, but they can be observed in the liver, adrenal glands, omentum, spinal canal, and eye (KAMIIE et al., 2009; VALLI et al., 2017). In humans, myelolipomas are more frequently observed in the adrenal glands (ZENG et al., 2015). Most extra-adrenal myelolipomas occur without other comorbidities in humans, but they may be accompanied by other diseases in some cases, such as small lymphocytic lymphoma/chronic lymphocytic leukemia, low-grade B-cell lymphoma, and ovarian steroid cell tumors (GHEITH et al., 2008; NOLL
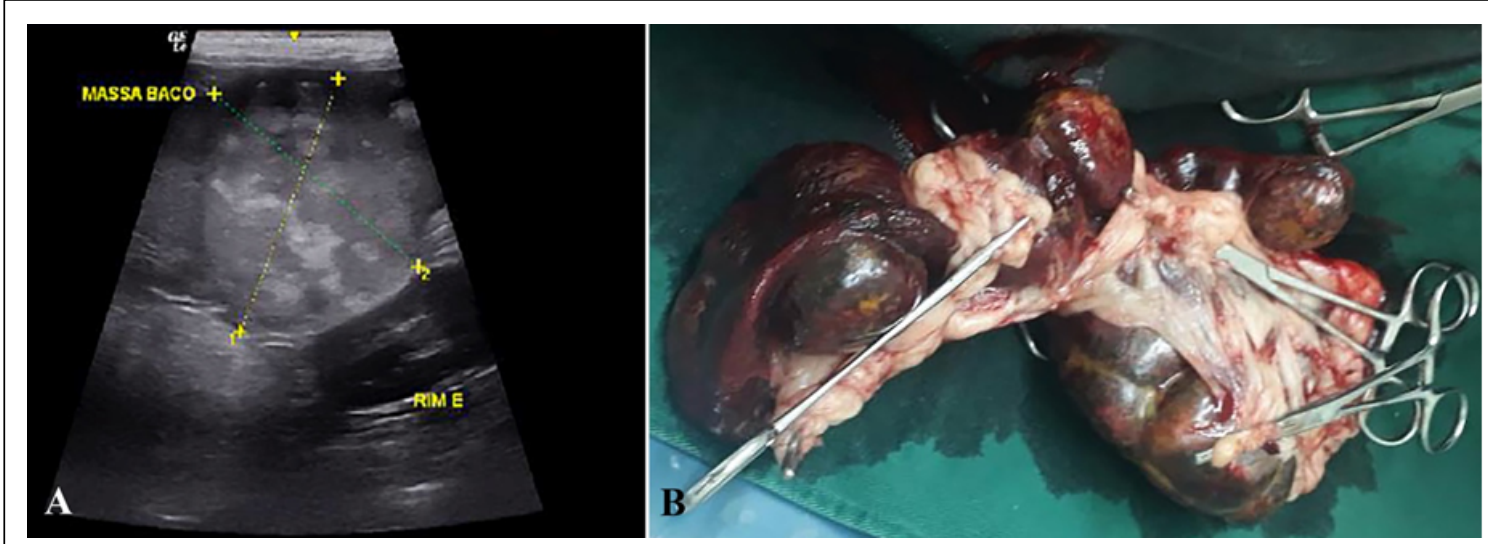

Figure 1 - Splenic myelolipoma in a dog. (A) Spleen ultrasonograph showing a mass with heterogeneous echotexture, mixed echogenicity, and irregular and poorly delimited margins. (B) Enlarged and multinodular spleen with red and yellow areas on the capsular surface of the nodules. 

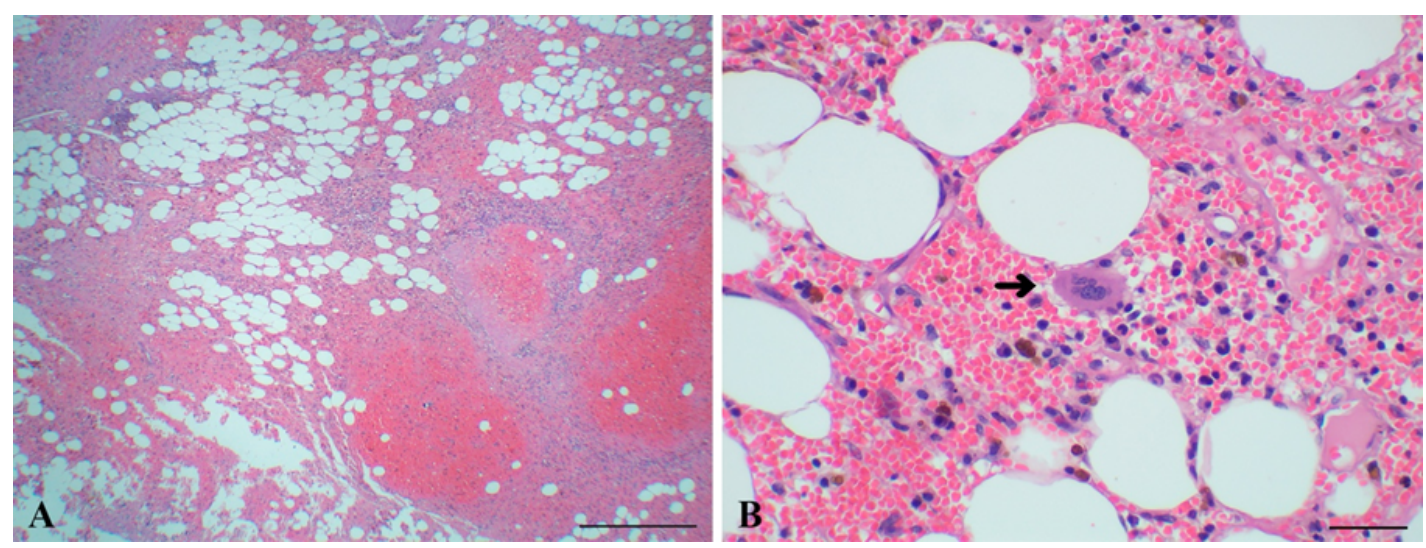

Figure 2 - Splenic myelolipoma in a dog. (A) A well-demarcated and unencapsulated mass composed of histologically welldifferentiated neoplastic adipose tissue with islands and nests of varying proportions of hematopoietic elements. HE. Bar, $200 \mu \mathrm{m}$. (B). Well-differentiated neoplastic adipose tissue intermixed with macrophages, lymphocytes, plasma cells, and a megakaryocytic cell (arrow). HE. Bar, $40 \mu \mathrm{m}$.

et al., 2013; ZHANG \& LÜ, 2011). Here, no other comorbidities associated with myelolipoma were observed. However, the animal had a history of mammary cancer, but without histological characterization of tumor type. Breast tumors usually metastasize to the regional lymph nodes, lungs, pleura, liver, diaphragm, adrenal glands, and kidneys, whereas they rarely metastasize to the spleen (De NARDI et al., 2017). Here, cells compatible with mammary tumors were not observed. In addition, no macroscopic evidence of metastasis was found during laparotomy in other organs.

The pathogenesis of myelolipomas is not yet well defined. These tumors are believed to be derived from bone marrow emboli that lodged in the adrenal glands or other sites; alternatively, embryonic primitive mesenchymal cells might be the source of this tumor. It has also been suggested that myelolipomas are the result of metaplastic transformation of adrenal stromal cells (or stromal cells from other sites) in response to stimuli (SHEN et al., 2014; ZENG et al., 2015).

The hematological changes observed in this case are related to the previous diagnosis of ehrlichiosis presented by the animal. In dogs, it has been reported that ehrlichiosis can cause leukopenia, with monocytopenia and thrombocytopenia (BORIN et al., 2009).

Myelolipomas are observed on ultrasound images as hyperechoic masses or nodules with homogeneous echotexture in which fat is the main component of the tumor (CARRILLO et al., 2012). However, when this neoplasm had a greater amount of non fatty material (blood, calcium, or myeloid tissue), the ultrasonographic appearance may have a more nonspecific heterogeneous pattern (CARRILLO et al., 2012). Here, ultrasonography revealed mixed echogenicity and heterogeneous echo texture. This tumor had a mixture of fat and non-fatty material components at approximately equal proportions.

After the surgical procedure, the animal showed no more clinical signs and, even nine months after the procedure, no changes were observed in the imaging examinations. Surgery is curative for myelolipoma, and patients with this tumor exhibit good prognosis after treatment (VALLI et al., 2017). Myelolipomas are rare neoplasms in dogs with no specific clinical signs but should be included among the differential diagnoses of enlargement of the spleen observed on ultrasound images.

\section{ACKNOWLEDGEMENTS}

This work was supported by Fundação de Amparo à Pesquisa e Inovação do Espírito Santo - FAPES and was financed in part by the Coordenação de Aperfeiçoamento de Pessoal de Nível Superior (CAPES), Brasil - Finance code 001.

\section{BIOETHICS AND BIOSSECURITY COMMITTEE APPROVAL}

The authors of this article declared, for all due purposes, the project that increased the present data has not 
been submitted for evaluation to the Ethics Committee of the University/Research Institute "Centro Universitário do Espírito Santo - UNESC," but we are aware of the content of the Brazilian resolutions of the National Council for Control of Animal Experimentation - CONCEA "http://www.mct.gov.br/index.php/ content/view/310553.html" if it involves animals. This is a case report of a sick dog that was brought to UNESC by the owner. Therefore, the diagnostic procedures were necessary and are part of the diagnostic routine. Thus, the authors assume full responsibility for the presented data and are available for possible questions, should they be required by the competent authorities.

\section{DECLARATION OF CONFLICT OF INTERESTS}

The authors declare no conflict of interest. The founding sponsors had no role in the design of the study; in the collection, analysis, or interpretation of data; in the writing of the manuscript, and in the decision to publish the results.

\section{AUTHORS' CONTRIBUTIONS}

All authors contributed equally for the conception and writing of the manuscript. All authors critically revised the manuscript and approved the final version.

\section{REFERENCES}

AL-RUKIBAT, R. K.; BANI, I., Z. A. Unusual presentation of splenic myelolipoma in a dog. The Canadian Veterinarian Journal, vol.47, n.11, p.1112-1114, 2006. Available from: $<$ https://www.ncbi.nlm.nih.gov/pmc/articles/PMC1624918/pdf/ cvj47pg1112.pdf $>$. Accessed: Jul. 18, 2020.

ALVES, G. V. et al. Mielolipoma gigante - relato de caso e revisão de literatura. Revista do Hospital de Clínicas de Porto Alegre. vol.26, n.1, p.80-82, 2006. Available from: <https:// www.lume.ufrgs.br/bitstream/handle/10183/164820/001021260. pdf? sequence=1\&isAllowed=y $>$. Accessed: Jul. 18, 2020.

BANDINELLI, M. B. et al. Estudo retrospectivo de lesões em Baço de Cães Esplenectomizados: 179 Casos. Pesquisa Veterinária Brasileira, vol.31, n.8, p.697-701, 2011. Available from: <https:// www.scielo.br/pdf/pvb/v31n8/a11v31n8.pdf >. Accessed: Jul. 18, 2020. doi: 10.1590/S0100-736X2011000800011.

BORIN, S. et al.Aspectos epidemiológicos, clínicos e hematológicos de 251 cães portadores de mórula de Ehrlichia spp. naturalmente infectados. Arquivo Brasileiro de Medicina Veterinária e Zootecnia, vol.61, n.3, p.566-571, 2009. Available from: $<$ https:// www.scielo.br/pdf/abmvz/v61n3/07.pdf>. Accessed: Jul. 17, 2020. doi: 10.1590/S0102-09352009000300007.

CARDY, R. H.; BOSTROM, R. E. Multiple splenic Myelolipomas in a Cheetah (Acinonyx jubatus). Veterinary Pathology, vol.15, p.556-558, 1978. Available from: <https://journals.sagepub.com/ doi/10.1177/030098587801500414>. Accessed: Jul. 15, 2020. doi: $10.1177 \% 2 \mathrm{~F} 030098587801500414$.

CARRILLO, J.D. et al. What is your diagnosis?. Journal of the American Veterinary Medical Association, vol.240, n.4, p.375-
376, 2012. Available from: <https://avmajournals.avma.org/doi/ pdf/10.2460/javma.240.4.375>. Accessed: Jul. 15, 2020.doi: 10.2460/javma.240.4.375.

De NARDI, A.B. et al. Neoplasias mamárias. In: DALECK, C.R.; De NARDI, A.B. Oncologia em cães e gatos. 2.ed. Rio de Janeiro: Roca, 2017. Chap. 40. p.498-516.

GHEITH, S. et al. Small Lymphocytic Lymphoma/Chronic Lymphocytic Leukemia in a Pelvic Myelolipoma. International Journal of Clinical \& Experimental Pathology. vol.2, n.1, p.9598, 2008. Available from: <https://www.ncbi.nlm.nih.gov/pmc/ articles/PMC2491389/pdf/ijcep0001-0095.pdf>. Accessed: Jul. $17,2020$.

KAMIIE, J. et al. Multicentric myelolipoma in a dog. The Journal of Veterinary Medical Science, vol.71, n.3, p.371373, 2009. Available from: <https://www.jstage.jst.go.jp/article/ jvms/71/3/71_3_371/_pdf $>$. Accessed: Jul 15, 2020. doi: 10.1292/ jvms.71.371.

MORANDI, F. et al. Imaging diagnosis - bilateral adrenal adenomas and myelolipomas in a dog. Veterinary Radiology \& Ultrasound, vol.48, n.3, p.246-249, 2007. Available from: $<$ https://onlinelibrary. wiley.com/doi/epdf/10.1111/j.1740-8261.2007.00237.x>. Accessed: Jul. 14, 2020. doi: 10.1111/j.1740-8261.2007.00237.x.

NAI, G. A. et al. Mielolipoma gigante bilateral da glândula adrenal. Jornal Brasileiro de Patologia e Medicina Laboratorial, vol.43, n.4, p.265-268, 2007. Available from: <https://www.scielo.br/ pdf/jbpml/v43n4/a08v43n4.pdf $>$. Accessed: Jul. 20, 2020. doi: 10.1590/S1676-24442007000400008.

NOLL, A. et al. Low grade B Cell Lymphoma Arising in a Background of Multifocal estra-adrenal Myelolipoma. Annals of Clinical \& Laboratory Science, vol.43, n.4, p.441-446, 2013. Available from: <http://www.annclinlabsci.org/content/43/4/441. full.pdf>. Accessed: Jul. 17, 2020.

SHEN, C. et al. A bilateral neoplasm in chest: a case report and literature review. BMC Surgery, vol.14, n.42, p.1-6, 2014. Available from: <https://www.ncbi.nlm.nih.gov/pmc/articles/ PMC4094594/pdf/1471-2482-14-42.pdf>. Accessed: Jul. 16, 2020. doi: 10.1186/1471-2482-14-42.

VALLI, V. E. et al. Tumors of the hemolymphatic system. In: MEUTEN, D.J. Tumors in Domestic Animals. 5.ed. Aimes: Wiley Blackwell, 2017. Chap.7. p.203-321.

ZENG, Y. et al. Giant myelolipoma in the spleen: a rare case report and literature review. International Journal of Surgical Pathology, vol.24, n.2, p.177-180, 2015. Available from: $<$ https://journals.sagepub.com/doi/full/10.1177/10668969156 17027?url_ver=Z39.88-2003\&rfr_id=ori:rid:crossref.org\&rfr_ dat $=$ cr_pub $\% 20 \% 200$ pubmed $>$. Accessed: Jul. 16, 2020. doi: $10.1177 / 1066896915617027$.

ZHANG, X.; LÜ, B. Ovarian steroid cell tumor, not otherwise specified (NOS): an unusual case with myelolipoma. International Journal of Gynecological Pathology, vol.30, n.5, p.460-465, 2011. Available from: <https://journals.lww.com/ intjgynpathology/Abstract/2011/09000/Ovarian_Steroid_Cell_ Tumor,_Not_OtherwiseSpecified.6.aspx >. Accessed: Jul. 15, 2020. doi: $10.1097 /$ PGP.0b013e31821643a3. 